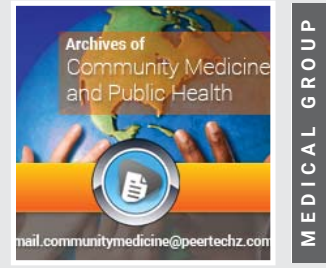

\title{
The COVID 19 pandemic from the primary care trenches
}

\section{Claudia Bujold*}

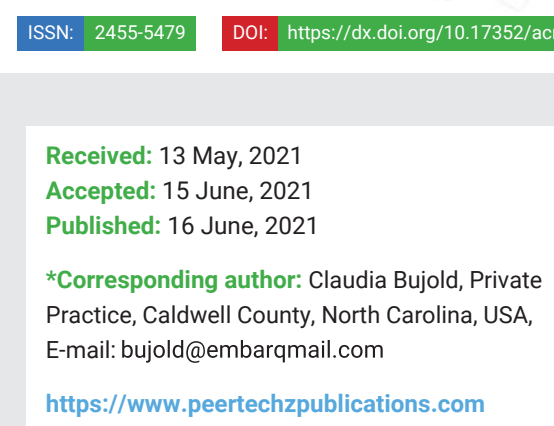

Private Practice, Caldwell County, North Carolina, USA

The crisis facing primary care practices across America is real on multiple fronts. The COVID 19 pandemic is exposing broad weaknesses in our healthcare system; those of us who work in this space are in crisis mode wondering if we will be able to survive until the end of the year and beyond. To understand how we got here I must take you back a few years.

I am a solo practitioner with a mid-level provider and have successfully practiced medicine for 33 years in a small town in the foothills of the western North Carolina. I practice all phases of medicine excluding obstetrics and continue to see my own patients in the hospital. I also do some work in the addiction medicine space and am a consultant for the State Targeted Response and Technical Assistance (STR-TA) program sponsored by the Substance Abuse Mental Health Services Association (SAMHSA), an agency within the Department of Health and Human Services. Our practice is certified by the National Committee for Quality (NCQA) as a Patient Centered Medical Home, a Diabetic Center of Excellence, and a Stroke/ Coronary Artery Center of Excellence. At one time our small practice employed a $\mathrm{PhD}$ psychologist, a PharmD, a Physical Therapist and a Dietician. All these people worked part time in my office. From 1995 and 2005 with this very capable team we were able to decrease our hospital admissions by $80 \%$. The team embrace and practiced high value/low cost healthcare. Admittedly (looking back), we were ahead of our time and mistakenly thought the insurance industry which included Medicaid, Medicare and third-party payers would reward us for out good work. Not so, I lost $\$ 100,000$ from my inpatient revenue because we were taking such good care of patients in the clinic settings.

At the end of 2015, the federal government shuttered the Meaningful Use program moving on to MIPS/MACRA and high value/low cost healthcare. All of he bonuses and additional payments we received from Medicare plans went away overnight. I lost another $\$ 100,000$ [1]. In addition, from 2006 through $2016,20 \%$ of our outpatient visits were lost to urgent care settings even though we had an open access schedule and could easily see these patients during the day [2]. As a result, we have been in a financial crisis mode ever since. I had to make the difficult decision to dismantle parts of our PCMH staff but did manage to hire a master's level mental health provider to maintain mental health services in our office. During all the chaos, I received a call from a Medicare consultant who was studying high functioning primary care practices offering high value at low cost. I was in the $7 \%$ of lowest cost in the Medicare system among my peers throughout the United States. Medicare was interested in learning the "secret sauce" allowing us to control costs.

Fast forward to January of 2020, we started to hear about a little-known corona virus in China. By March of 2020, it was here in the United States; a virus for which we were completely unprepared. At the end of April 2020, our patient volumes and gross revenues were down $25 \%$. I have the good fortune to work with an excellent health care banker, a very knowledgeable certified public accountant who specializes in small businesses, and an information technology company for many years. They are a part of our team. They were all aware how slim our profit margins had been for several years from previous work they had done with us. Together we crafted a plan.

In a financial crisis of this magnitude, first and foremost, you need leadership and that leadership came from myself and my office manager. My staff had two fears-were we going to close our doors and were they going to have jobs? The most valuable members of our clinic are our employees and I made sure they all knew that; I also assured them no one was going to loose their job even if we had to take out a business equity line to make sure they were paid. A couple of my staff have school age children; we will support them with their needs there too. It was the least I could do.

Fortunately, the federal government was aware of the impact the virus was having on small businesses. We applied for the CARES Act stimulus money on the first weekend it was available. Our team then researched and discussed how 
we were going to protect our team (one of our team members has multiple sclerosis and another is an insulin dependent diabetic) and our patients. We completely re-engineered how we would see patients in the office. We developed screening procedures when talking with patients on the phone and had another layer of screening done when patients came to the clinic. No one would come into the clinic if they had a fever or infection of any kind. All these patients were examined in the parking lot and tested there if tests were indicated. Through our accountable care organization, we quickly were up and running with a telemedicine option for our patients. Our front office staff aggressively put patients at ease and reassured them they would be safe coming to the office for their regular appointments. In April 2020, our patient volume and gross revenue was down about 25\% compared with April of 2019; in May 2020 our gross revenue and patient volume was down $15 \%$ and by June 2020 we were about back to normal with both patient volumes and revenue.

I met with my accountant at the end of June and we both felt comfortable paying our back taxes through June $15^{\text {th }}$ of 2020 . I also had a significant amount of cash reserve built up thanks to the CARES Act and the Department of Health and Human Services. We really had no cash reserves from 2015 until now.

Just when the outlook for our clinic started looking more promising another crisis occurred. My office manager came down with the corona virus. She and her husband had positive tests as did her sister. We had been so careful and vigilant. We preached so much about social distancing and wearing masks when away from the clinic. How could this happen? Most cases of the virus are contracted at home. My office manager's husband works in a small business with five other employees; there are people coming into their business on a regular basis and the company owner felt placing plastic screens up at the cash register would be sufficient to protect his employees. There was no social distancing and no mask requirement. During a bit of contact tracing we discovered another employee in the business tested positive and most likely passed it on to her husband who then brought it home and passed it on to my office manager who then passed it on to her sister. No one else in my office has had any symptoms but we need to be ever vigilant. What happened to personal responsibility? I believe we have not done enough as family physicians to emphasize to the public how masks and social distancing can prevent infection and save lives.

Two weeks ago, we had not had a positive test for COVID 19 in my office in our patient population. Since then we have had 13 positive tests for COVID 19 among our patient population. Since the governor "opened up" the economy in a limited fashion, most people in North Carolina interpreted this as business as usual (as in before the pandemic hit us in March). Among my staff now I detect a subtle change in attitudes. There is a bit more fear, a bit more anxiety. We are really at the tip of the iceberg and we expect to see many more cases of the virus as we move into July and August. School will start soon, and this is bringing another layer of complexity into our small office.
One of our nurses will be leaving her position because she does not have any day care options or relatives to take care of her school aged children who are five and nine. It is hard to replace hard working, well intentioned team members and with the complexity of the care we provide it takes a good two years to train a new nurse to understand all the moving parts in our patient centered environment.

Moving forward, we all still have concerns as we approach the $3^{\text {rd }}$ and $4^{\text {th }}$ quarters of 2020 and 2021. Much uncertainty remains and now the crisis appears to be roaring forward as summer peaks. Again, I ask - is it such a burden to social distance and wear masks? I cannot thank all my team members enough for the contributions they all make to keep us afloat.

Clearly, as a nation, our policy makers must consider placing more money in the hands of primary care physicians. $7-15 \%$ of our healthcare dollars should be reallocated to primary care depending on the study (that number currently stands at $3-5 \%)[3]$. We quickly need to move away from a system that rewards our work based on the volume of people we see. Maybe a capitated system should be considered. Under capitation, we would not find ourselves in a financial crisis as patients stopped coming to our office. We should embrace telemedicine and be reimbursed for it just as if a patient were in our office. Already, we are hearing our payers stating they may not pay for this in the future. Without foundational changes in primary care we will never have a successful health care system.

\section{References}

1. Bujold E (2017) The Impending Death of the Patient Centered Medical Home JAMA Intern Med 177: 1559-1560. Link: https://bit.ly/3xeRaT8

2. Ganguli I, Shi Z, Orav EJ, Rao A, Ray KN, et al. (2020) Declining Use of Primary Care Among Commercially Insured Adults in the United States, 2008-2916. Ann Intern Med 172: 240-247. Link: https://bit.ly/3xt1w1X

3. Milbank Memorial Fund (2018) New England States to Collaborate on Key Health Policy Issues News Article. Link: https://bit.ly/3pVRrYB

Discover a bigger Impact and Visibility of your article publication with

Peertechz Publications

Highlights

* Signatory publisher of ORCID

* Signatory Publisher of DORA (San Francisco Declaration on Research Assessment)

* Articles archived in worlds' renowned service providers such as Portico, CNKI, AGRIS, TDNet, Base (Bielefeld University Library), CrossRef, Scilit, J-Gate etc.

* Journals indexed in ICMJE, SHERPA/ROMEO, Google Scholar etc.

* OAI-PMH (Open Archives Initiative Protocol for Metadata Harvesting)

* Dedicated Editorial Board for every journal

* Accurate and rapid peer-review process

* Increased citations of published articles through promotions

* Reduced timeline for article publication

Submit your articles and experience a new surge in publication services (https://www.peertechz.com/submission).

Peertechz journals wishes everlasting success in your every endeavours.

Copyright: $\odot 2021$ Bujold C. This is an open-access article distributed under the terms of the Creative Commons Attribution License, which permits unrestricted use distribution, and reproduction in any medium, provided the original author and source are credited. 